Sirenko Natalia, Dr. of Economics, Professor, Head of the Department of Finance, Banking and Insurance, Mykolayiv National Agrarian University, Mykolayiv, Ukraine

ORCID ID: 0000-0003-1660-1073

e-mail: sirenko@mnau.edu.ua

Mikuliak Kateryna, Assistant of the Department of Finance, Banking and Insurance, Mykolayiv National Agrarian University, Mykolayiv, Ukraine

ORCID ID: 0000-0001-8317-0360

e-mail: mikulyak@mnau.edu.ua

Oleynichenko Kristina, a student of the Accounting and Finance Faculty, Mykolayiv National Agrarian University, Mykolayiv, Ukraine

ORCID ID: 0000-0002-1506-3624

e-mail: cristina.tina1818@gmail.com

\title{
The State and Tendencies of Development of Agrarian Receipts in the Ukrainian Agrarian Sector
}

Abstract. Introduction. The urgency of finding alternative instruments of financial support for agricultural enterprises is growing and the problem can be solved only with the maximum consideration of the specifics of agroindustrial production as a subject of lending. Due to the lack of liquid collateral, the lack of proper government support for economic entities, it is optimal to use agrarian receipts as a modern lending tool.

Purpose. The purpose of the research is to reveal the essence and emergence of agrarian receipts as a tool for crediting the sustainable development of agricultural producers, as well as to identify possible trends in the future.

Results. This article describes the essence and conditions of agrarian receipts in the agrarian sector of the Ukrainian economy. It has been established that agrarian receipts are a convenient and simple tool that help to involve agricultural producers in cooperation with various stakeholders. The interpretation of commodity and financial agrarian receipts in accordance with the amended legislative acts is given. The stages of preparation of agrarian receipts, as well as the advantages of processing agrarian receipts, are summarized. The state of financing and making agrarian receipts in Ukraine since the beginning of the instrument has been analyzed. The volume of financing of agricultural sector entities by means of agricultural receipts for 2020 has been estimated and financial resources have been increased in the long term, which is related to the improvement of the legislation on agricultural receipts, in terms of simplifying them and reducing the order of issuance, circulation and suspension.

Conclusions. Therefore, agrarian receipts can become a major financial instrument for the economic growth of the agricultural sector and give an impetus for the development of agricultural producers through additional sources of financing, as evidenced by the results of research. Improving legislation to simplify and reduce the cost of issuing, circulating and terminating an agricultural receipt will increase the ease of use, as well as improve agricultural producers access to finance and production resources. In order to further promote this tool, it is necessary to continue training among agricultural producers, thereby raising their awareness, attracting new potential creditors from among international companies, which will help strengthen the competitive position of the agricultural sector in the market environment.

Keywords: agricultural receipt; agricultural enterprises; commodity agricultural receipt; financial agricultural receipt; agricultural producers; farmers.

\section{УдК 336.647:648}

Сіренко Н. М., д-р екон. наук, професор, завідувач кафедри фінансів, банківської справи та страхування, Миколаївський національний аграрний університет, м. Миколаїв, Україна

Мікуляк К. А., асистент кафедри фінансів, банківської справи та страхування, Миколаївський національний аграрний університет, м. Миколаїв, Україна

Олейніченко К. О., здобувач вищої освіти обліково-фінансового факультету, Миколаївський національний аграрний університет, м. Миколаїв, Україна

\section{Стан та тенденції розвитку аграрних розписок в аграрному секторі економіки України}

Анотація. Актуальність пошуку альтернативних інструментів фінансового забезпечення аграрних підприємств зростає, розв'язати проблему можна лише з максимальним урахуванням специфіки агропромислового виробництва як суб'єкта кредитування. Через нестачу ліквідної застави, відсутність належної підтримки з боку держави для суб'єктів господарювання оптимальним є використання аграрних розписок як сучасного інструмента в кредитуванні.

Стаття надійшла до редакції: 19.05.2020

Received: 19 May 2020 
У статті розкрито сутність та умови виникнення аграрних розписок в аграрному секторі економіки України. Встановлено, що аграрні розписки є зручним й простим інструментом, який допомагає залучити сільськогосподарських товаровиробників до співпраці з різними стейкхолдерами. Наведено тлумачення товарних й фінансових аграрних розписок відповідно до змінених законодавчих актів. Узагальнено етапи підготовки аграрної розписки, а також переваги щодо оформлення аграрних розписок. Проаналізовано стан фінансування та укладання аграрних розписок в Україні від початку започаткування інструмента. Здійснено прогноз обсягів фінансування суб'єктів аграрного сектору за допомогою аграрних розписок на 2020 р. та встановлено обсяги нарощування фінансових ресурсів у перспективі, що пов'язано із вдосконаленням законодавства про аграрні розписки, в частині їх спрощення та здешевлення порядку видачі, обігу та припинення.

Таким чином, аграрні розписки можуть стати основним фінансовим інструментом економічного зростання аграрного сектору та дати поштовх до розвитку сільськогосподарських товаровиробників завдяки додатковим джерелам фінансування, про що свідчать результати дослідження. Удосконалення законодавства щодо спрощення та здешевлення порядку видачі, обігу та припинення аграрної розписки підвищить простоту у користуванні, а також сприятиме покращенню доступу сільськогосподарських товаровиробників до фінансових та виробничих ресурсів. Для подальшої популяризації даного інструмента необхідно продовжувати інформування агровиробників, тим самим підвищуючи їх обізнаність, залучаючи нових потенційних кредиторів з-поміж міжнародних компаній, що надасть змогу посилити конкурентні позиції аграрного сектору в ринковому середовищі.

Ключові слова: аграрна розписка; сільськогосподарські товаровиробники; товарна аграрна розписка; фінансова аграрна розписка.

Formulation of the problem. Agriculture is the basis of the national economy on which the country's food security depends. The state of development of agricultural producers and, as a result, the volume of their products is one of the most important indicators of the quality of agrarian reforms and programs implemented in the country, the implementation of which requires appropriate financial support.

The urgency of finding alternative tools for financial support for agricultural enterprises is growing and to solve the problem is possible only with maximum consideration of the specifics of agro-industrial production as a subject of lending. Due to the lack of liquid collateral, lack of proper state support for businesses, it is optimal to use agricultural receipts as a modern tool in lending.

Analysis of recent research and publications. N. Bondarenko [3], V. Zharenko [5], Y. Lupenko [6], V. Feshchenko [6] devoted their research to the issues of distribution and development of agrarian receipts in Ukraine, the mechanism of their implementation. Also, N. Pravdyuk [7], A. Rusnak [11], S. Prokhorchuk [11], A. Karnaushenko [11], N. Radchenko, S. Stender [14], A. Narumov, O. Stoyko [15] and others studied this subject.

However, most authors emphasize the need for further research to identify the need for the distribution of agricultural receipts in Ukraine, because this issue is relevant and needs further study.

Formulation of research goals. The purpose of the study is to reveal the nature and mechanism of agricultural receipts as a tool for lending to the sustainable development of agricultural producers, as well as to identify possible trends in the future.

Presentation of the main research material. The adoption of the Law of Ukraine "On Agrarian Receipts" [8] in 2012 prompted the emergence of agricultural receipts as effective tools for financing the needs of agricultural producers in order to facilitate their cooperation with key stakeholders and ensure proper implementation of their obligations.

However, in practice, this institute came into operation in 2015 after the implementation of a number of measures defined in the joint order of the Ministry of Agrarian Policy and Food of Ukraine with the Ministry of Justice of Ukraine №331 / 1471/5 "On the introduction of a pilot project to test the introduction of agricultural receipts „From 04.09.2014, namely the approval of a number of bylaws to implement the Law adopted in 2012 [13].

In order to speed up the implementation of agricultural receipts (obtaining financing for the replenishment of working capital, purchase of equipment, high-quality seeds and other production resources) in Ukraine since 2015, the project "Agricultural receipts in Ukraine", which is implemented by the International Finance Corporation (IFC) with the support of the Swiss State Secretariat for Economic Affairs. The main partners of the Project are public authorities (Ministry of Economic Development, Trade and Agriculture, Ministry of Justice of Ukraine); private sector (suppliers of material and technical resources, banking institutions, grain traders), and international organizations. The agrarian receipt was first used in practice in 2015 in Poltava region. Since 2016, the experience has been extended to Mykolayiv, Kharkiv, Cherkasy and Vinnytsia regions, and since 2018 all regions in Ukraine use this lending tool. The project aims to help raise $\$ 0.5$ billion in funding for the agricultural sector using this tool [4].

Agricultural receipts are a convenient and simple tool that helps to attract agricultural producers to cooperate with suppliers of stocks (seeds, fertilizers, spare parts, fuels and lubricants, agricultural machinery), distributors, banking and non-banking financial institutions, contractors and services, traders, processors and other market participants [13].

We agree with the opinion of A. Rusnak, S. Prokhorchuk and A. Karnaushenko [11] that agricultural receipts are a special type of lending that allows agricultural producers to obtain financial or material resources necessary for a quality business process, in order to generate future profits, and the calculation for the use of these resources occurs after the harvest for which these resources are spent [11]. 
Under the law number 2805 from 24.01.2020 "On amendments to some legislative acts of Ukraine concerning the operation and circulation of agricultural receipts" agrarian receipt is a non-equity security paper which fixes unconditional obligation of the debtor, which provides collateral to deliver agricultural products or pay money on the terms specified therein [9].

In order to simplify and reduce the cost of issuance, circulation and termination of agricultural receipts, the bill provides for the existence of agricultural receipts in the form of an electronic document in the Register of agricultural receipts. Transactions on issuance, change of conditions, circulation, encumbrance of obligations, ensuring the fulfilment and termination of obligations under the agricultural receipt will be made in the Register of agricultural receipts. In this case, the parties will be able to carry out operations for the issuance, transfer or amendment of the agricultural receipt both independently, using their electronic digital signature, and applying to a notary [9]. The bill also proposes an updated list of details of separate financial and commodity agricultural receipts, which is caused by the specifics of their content and features of the fixed obligations, as well as slightly changed the interpretation of the nature and mechanisms of these financial instruments (Fig. 1).:

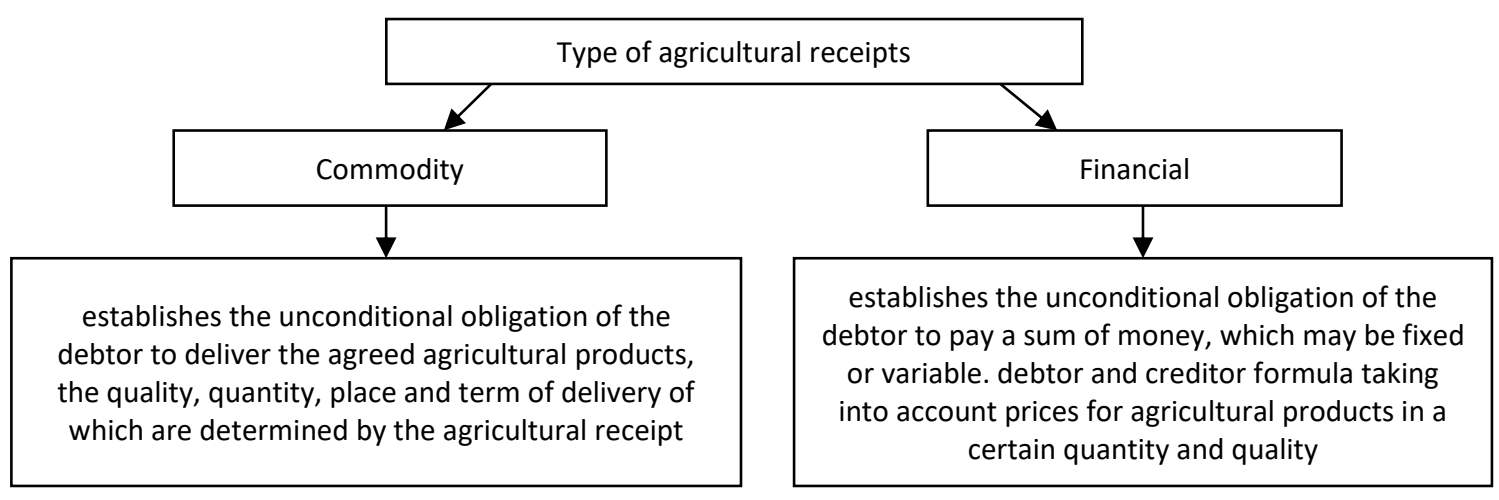

Figure 1 - Types of agricultural receipts in the agricultural sector

Source: formed by the authors according to $[8,9]$

To issue an agricultural receipt requires documents certifying the powers of both parties as in the execution of any contract, as well as title documents to the land (certificate of ownership, lease, etc.). Land rights must be duly registered in accordance with the Law of Ukraine "On state registration of real rights to immovable property and their encumbrances" [13].

The agricultural receipt has its "life cycle" and includes five stages of preparation (Fig. 2)

The stages of preparation of the agrarian receipt

1 Issuance of an agricultural receipt - conclusion of a contract for the provision of funds / supply of goods / performance of works / provision of services and direct issuance of an agricultural receipt

Monitoring - on the basis of the Law "On agricultural receipts" the creditor monitors the availability of

Figure 2 - "Life cycle" of agricultural receipts

Source: formed by the authors according to [13] 
Agricultural receipts do not require mandatory payment of interest and the final cost of financing for agricultural producers will depend on the conditions agreed by the parties. In particular, according to the financial agricultural receipt, the amount to be paid will depend on the value of agricultural products, which is included in the formula, on the day of fulfillment of the obligation. If it is a commodity agricultural receipt, the cost of financing will depend on the contractual value of the agricultural receipt as of the date of its conclusion and the value of products that are the subject of delivery of agricultural producers on the date of delivery [1].

However, the agricultural receipt has a number of positive aspects for agricultural producers, including the ability to replenish working capital; ease of preparation, design and use; short decision time; transparency of conditions; flexibility and the possibility of introducing additional conditions within the current legislation.

In total, since the beginning of the implementation of this instrument in Ukraine, 2116 agricultural receipts have been issued and more than UAH 14.5 billion has been attracted to the agricultural sector. In October 2016, Mykolayiv region joined the pilot project "Agricultural receipts in Ukraine". Thus, FG "Matrix" of Berezansky district concluded the first agricultural receipts, which allowed the farm to attract 2.3 million $\mathrm{UAH}$ of additional working capital for the purchase of material and technical resources.

As of 2019, Kherson, Sumy, Ternopil and Vinnytsia regions became the leaders in concluding agricultural receipts (Fig. 3).

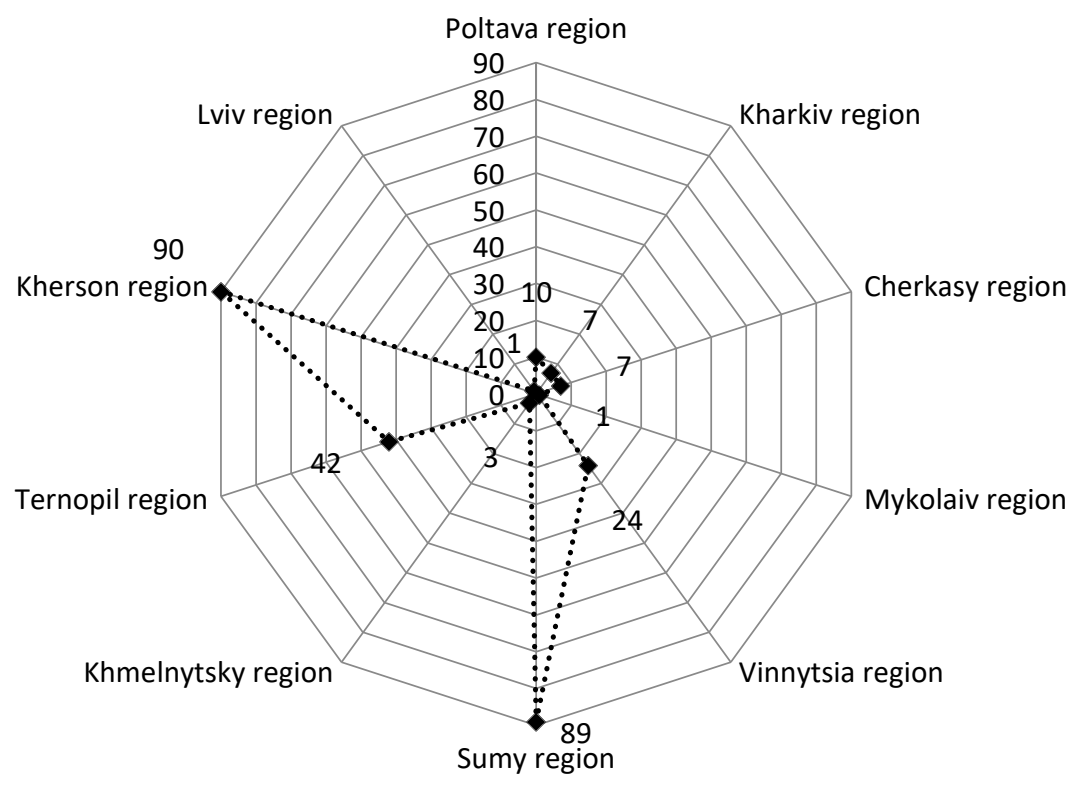

Figure 3 - Status of agricultural receipts in Ukraine in 2019

Source: built by the authors according to $[11,16]$

The tendency to increase this tool for financing agricultural producers and the results of statistical, retrospective and graphical research methods suggest that in the future growth of funding for this type of liability. Thus, the projected value of attracting financial resources by the end of 2020 is UAH 11,906.0 million, which is UAH 106.0 million more than in the previous year of the study (Fig. 4). The calculated forecast indicator shows a positive trend of increasing lending under this instrument, which is caused by the escalation of measures of public authorities to improve the legislation on agricultural receipts in the direction of simplifying and reducing the cost of issuance, circulation and termination of agricultural receipts.

The purpose of legislative changes is to expand the scope of agricultural receipts in the agricultural sector, which improves the existing mechanisms for working with agricultural receipts. unlocking the potential to increase funding for agricultural producers, as well as expanding the range of entities that can issue agricultural receipts, through agricultural service cooperatives, members of which own agricultural land or the right to use such land subject to notarization certified consent of such a member to the issuance of such an agrarian receipt [9].

In addition to the pledge of the future harvest, the legislation provides for the possibility and procedure of pledge on the agricultural receipt of live animals and products of animal origin, the products of their primary processing [9]. Thus, in the Sambir district of Lviv region, the farm "Hope" took advantage of a new financial instrument. A loan was secured from the local private enterprise Cooperative Solidarity on the security of 25 tons of whole cow's milk, which the debtor is to deliver to the creditor during the year according to the agricultural receipt. 


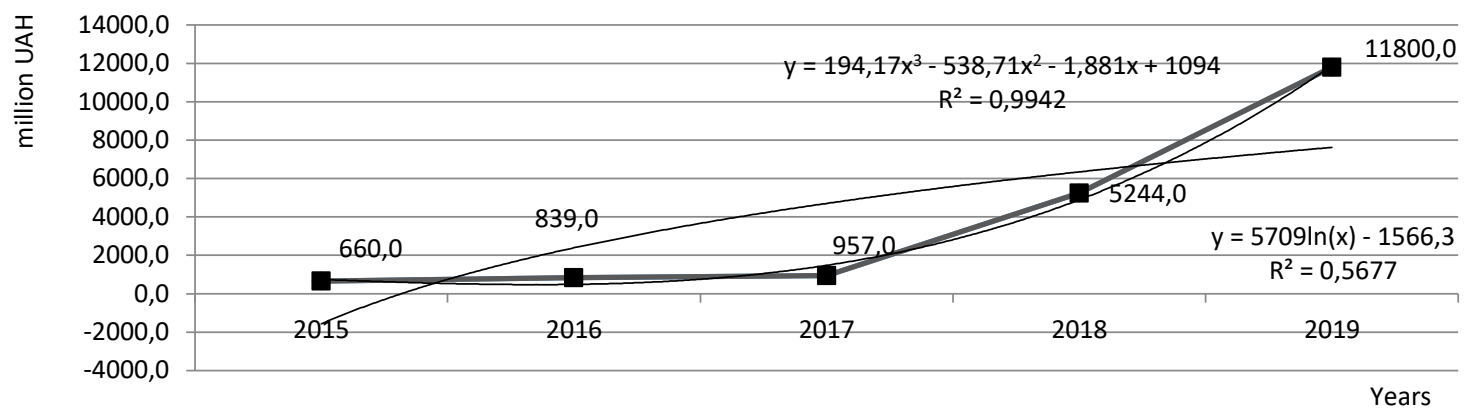

Figure 4 - Forecast values of funding for agricultural receipts

Source: calculated by the authors according to $[1,4,13,14,16]$

Thus, agricultural receipts become an effective financial instrument not only in the field of crop production but also found demand in the field of animal husbandry.

Conclusions. The agricultural receipt is a universal tool for business development and growth. It is an effective financial instrument adapted to the needs of agricultural producers. Attracting borrowed resources, taking into account the peculiarities of doing business in agriculture is an economic necessity in today's conditions. Agricultural receipts can become the main financial instrument of economic growth of the agricultural sector and give impetus to the development of agricultural producers through additional sources of funding, as evidenced by the results of the study. Improving the legislation in terms of simplifying and reducing the cost of issuance, circulation and termination of agricultural receipts will increase ease of use, as well as improve the access of agricultural producers to financing and production resources. To further promote this tool, it is necessary to continue training among agricultural producers, thereby raising their awareness, attracting new potential lenders from among international companies, which will strengthen the competitive position of the agricultural sector in the market environment.

\section{References:}

1. Aghrarni rozpysky v Ukrajini. Retrieved from: https://cutt.ly/lypxzuw.

2. Aghrarni rozpysky: novi mozhlyvosti dlya vyrobnykiv svynyny. Retrieved from: https://cutt.ly/zypxtQT.

3. Bondarenko, N. V. (2015). Agricultural Management, Business: Alternative instruments for lending to the agricultural sector. Naukovyj visnyk NUBIP Ukrajiny. Serija: Economika, 222, 71-79 [in Ukrainian].

4. Doviryty do proektu ahrarnykh rozpisok, shcho zrostaye - propozytsiyi. Retrieved from: https://www.ukrinform.ua/rubriceconomy/2640432-dovira-do-mehanizmu-agrarnih-rozpisok-soroku-zrostae-eksperti.html [in Ukrainian].

5. Zharenko, V. F. (2013). The pledge of the future crop under the agrarian receipt. Pravovyy visnyk akademiyi bankivs'koyi spravy, 2, 8287 [in Ukrainian].

6. Lupenko, Ju. O. \& Feshhenko, V. V. (2014). Capital market for financing small and medium-sized businesses in the agricultural sector. Finansy, oblik ta audyt, 68-78 [in Ukrainian].

7. Pravdjuk, N. L. (2016). Agrarian receipts as an alternative form of lending to agricultural enterprises: an accounting aspect. Oblik $i$ finansy, 4, 69-79 [in Ukrainian].

8. Zakon Ukrajiny «Pro aghrarni rozpysky» (2012). Retrieved from: https://zakon.rada.gov.ua/laws/main/5479-17 [in Ukrainian].

9. Proekt Zakonu pro vnesennya zmin do deyakykh zakonodavchykh aktiv Ukrayiny shchodo funktsionuvannya ta obihu ahrarnykh rozpysok №2805 vid 24.01.2020. Retrieved from: http://w1.c1.rada.gov.ua/pls/zweb2/webproc4_1?id=\&pf3511=67987 [in Ukrainian].

10. Rozshyrennya mozhlyvostey ahrarnykh rozpysok. Retrieved from: https://agroregisters.com.ua/rozshyrennya-mozhlyvostej-agrarnyhrozpysok/.

11. Rusnak, A. V., Prokhorchuk, S. V. \& Karnaushenko, A. S. (2019). Current status and prospects of development of agricultural receipts in Ukraine. Ekonomichna nauka, Retrieved from: https://cutt.ly/WypzGAC [in Ukrainian].

12. Sirenko, N. \& Melnyk, O. (2013). Budget and tax incentives for innovative development of the agrarian sector of the economy. Ekonomist, Retrieved from: http://nbuv.gov.ua/UJRN/econ_2013_4_9 [in Ukrainian].

13. Sproshhennja aghrarnykh rozpysok. Retrieved from: https://www.ukrinform.ua/rubriceconomy/ 2699971minagroiniciuesprosennata-zdesevlenna-oformlenna-agrarnihrozpisok.html [in Ukrainian].

14. Stender, S. V. (2017). Agrarian receipt and promissory note form as alternative sources of credit to agricultural enterprises. Ekonomika i suspiljstvo, 8, 800-805 [in Ukrainian].

15. Stojko, O. Ja. (2015). Capitalization of agricultural enterprises through the use of agricultural receipts. Efektyvna ekonomika. Retrieved from: http://www.economy.nayka.com.ua/?op=1\&z=6229 [in Ukrainian].

16. Ukrayins'ki ahrariyi oformyly ahrarnykh rozpysok mayzhe na 12 mil'yardiv. Retrieved from: https://cutt.ly/FypxMad. 